\title{
Dose-dependent expression changes of early response genes to ionizing radiation in human lymphoblastoid cells
}

\author{
XIAN-HUI LONG ${ }^{1,2}$, ZENG-QIANG ZHAO ${ }^{1}$, XING-PENG HE ${ }^{2}$, HUI-PING WANG ${ }^{1}$, QIN-ZHI XU1', \\ JING AN ${ }^{1}$, BEI BAI $^{1}$, JIAN-LI SUI ${ }^{1}$ and PING-KUN ZHOU ${ }^{1}$ \\ ${ }^{1}$ Department of Radiation Toxicology and Oncology, Beijing Institute of Radiation Medicine, Beijing 100850; \\ ${ }^{2}$ The College of Public Health, Nanhua University, Hengyang, Hunan Province 421000, P.R. China
}

Received November 28, 2006; Accepted January 10, 2007

\begin{abstract}
The sensitivity of cancer cells as well as normal cells in response to ionizing radiation (IR) is believed to be associated with the early inducible expression of specific genes. Using cDNA microarray technology, here we explored and compared the global transcriptional changes in human lymphoblastoid AHH-1 cells irradiated with 0.05-, 0.2-, 0.5-, 2.0- and 10-Gy doses of $\gamma$-rays $4 \mathrm{~h}$ after exposure. A dose as low as $0.05 \mathrm{~Gy}$ was efficient in inducing a transcriptional response including the up-regulation of 25 genes, some of which are involved in signal transduction pathways, e.g. BMPR2, GPR124, MAPK8IP2 and AGGF1, and the downregulation of 18 genes. Expression of some genes was altered only at a specific dose. Most importantly, we discovered a number of radiation-response genes, e.g. DNA repair gene $X P C$, tumor protein p53 inducible protein 3 gene (TP53I3), immediate early response 5 gene, whose transcriptional levels were increased or depressed by IR in a dose-dependent trend within the dose range 0.05-10 Gy. The dose-dependent induced expression of TP53I3 and XPC was confirmed by Northern blot analyses. Using quantitative real-time PCR, we further confirmed that $X P C$ gene induction was dose dependent as well as time dependent, reaching a peak $4 \mathrm{~h}$ post- 2 Gy and $10 \mathrm{~h}$ post-0.05 Gy. The maximum induced expression level of the XPC gene was higher after 2 Gy (3.2fold) than $0.05 \mathrm{~Gy}$ (1.93-fold). The identification of these radiation-inducible genes, especially those exhibiting a dosedependent response, not only expands our knowledge of the mechanisms underlying the diverse biological effects induced by IR, but provides candidates for developing novel biomarkers of radiation injury.
\end{abstract}

Correspondence to: Dr Ping-Kun Zhou, Department of Radiation Toxicology and Oncology, Beijing Institute of Radiation Medicine, 27 Taiping Road, Haidian District, Beijing 100850, P.R. China E-mail:zhoupk@nic.bmi.ac.cn

Key words: radiation effect, gene expression, radiation-inducible gene, biomarker

\section{Introduction}

It is well documented that the biological effects induced by exposing mammalian cells to ionizing radiation (IR) are closely associated with radiation doses and dose rates. Larger doses which are used for radiotherapy of cancers lead to more severe injury, while low-dose radiation (i.e. $<0.5$ Gy) may result in a complex scenario of cellular responses that are either protective or supra-lethal according to the dose, e.g. adaptive response (1-7), hyper-radiosensitivity phenomenon as well as the inverse dose-rate effect (8-10). These low-dose radiation responses cannot thus be entirely predicted by extrapolation from the data obtained from large acute exposures. It has been suggested that some specific mechanistic pathways are induced by exposure to a specific dose range of IR.

The inducible alteration in gene expression is a fundamental molecular event of mammalian cells in response to ionizing radiation, and the fate of cells will at least partially depend upon the inducible changes in expression of some genes involved in these complex regulatory pathways resulting in cell cycle delays, cell killing or apoptosis and DNA repair (11-15). The cDNA microarray technology allowing a large-scale expression profiling analysis can provide tremendous information for elucidating the complex cellular response to radiation. Until now, a great number of radiation-inducible target genes have already been identified. Some of the inducible genes were identified in cells exposed to high and even supra-lethal doses of IR $(11,16-23)$, low doses or low dose rates $(13,23-28)$. These reports provide very valuable information for understanding the precious mechanisms of the diverse effects of IR. A simultaneously comparative analysis of gene responses to radiation from low, medium to high doses should be more informative for identifying the inducible genes with a dose-dependent expression. The aim of the present study was to identify such genes responding to low-dose radiation or with an inducible expression change in a dose-dependent manner towards the elucidation of the mechanisms of radiation effects and the development of novel biomarkers for the identification or classification of individuals with different radiosensitivity or for predicting normal tissue injury of patients during radiotherapy.

For this purpose, we used cDNA microarray technology to compare the global transcriptional changes of human 
lymphoblastoid AHH-1 cells $4 \mathrm{~h}$ after exposure to $\gamma$-rays of graded doses from 0.05-10 Gy. Our study identified a number of genes with dose-dependent expression trends and also a set of low-dose responsive genes. Using Northern blot hybridization and sensitive quantitative real-time PCR, further analyses of changes in expression of the TP53I3 gene and DNA repair gene $X P C$ also revealed dose- and/or timedependent responses.

\section{Materials and methods}

Cell culture and irradiation. The human lymphoblastoid AHH-1 cells were cultured in RPMI-1640 medium supplemented with $10 \%$ fetal bovine serum, $100 \mathrm{U} / \mathrm{ml}$ of penicillin and $100 \mu \mathrm{g} / \mathrm{ml}$ of streptomycin at $37^{\circ} \mathrm{C}$ in a humidified, $5 \% \mathrm{CO}_{2}$ atmosphere. Exponentially growing cells were irradiated at room temperature using a cobalt-60 $\gamma$-ray source at a dose rate of either $1.7 \mathrm{~Gy} / \mathrm{min}$ (for doses $\geq 0.5 \mathrm{~Gy}$ ) or $0.96 \mathrm{cGy} / \mathrm{min}$ (for doses 0.2 and $0.05 \mathrm{~Gy}$ ). For sham-radiation control, the cell cultures were set in the radiation room for an identical time as a corresponding dose while the cobalt source remained under water and sealed (without exposure). After irradiation, cells were cultured for $4 \mathrm{~h}$ and then harvested to prepare RNA extracts.

RNA isolation and microarray analysis. Total RNA was isolated from irradiated and sham-irradiated cells using TRIzol reagent (Invitrogen, Carlsbad, CA, USA) according to the manufacturer's instructions. Twenty $\mu \mathrm{g}$ of total RNA from irradiated or sham-irradiated cells was used as a template for generating Cy3- or Cy5-labeled cDNA probes after in vitro reverse transcription reaction (RT). Experimental conditions for the RT reaction and cDNA hybridization were performed as previously described (29). BiostarH-140s cDNA microarray (Biostar, Shanghai, P.R. China) was used which contains cDNA probes corresponding to 14,100 specific human genes that were scanned by ScanArray 4000 (Packard/Perkin Elmer, MN, USA). The intensities of the fluorescent images were captured, and the data were processed using GenePix Pro 3.0 imaging software (Axon Instruments, Foster City, CA, USA). Expression ratios were normalized to those of a set of forty housekeeping genes with a theoretical ratio of 1.0. For each dose, two independent microarray hybridization experiments were carried out using a mix of Cy3- and Cy5-labeled cDNA from control and irradiated AHH-1 cells, respectively. Fluoro-chromes were swapped between the first and second experiment. Data for a spot were defined as effective if the raw intensity value of both Cy3 and Cy5 was >200 after back-ground correction.

Semi-quantitative RT-PCR and quantitative real-time PCR. RT-PCR was used to semi-quantify the mRNA expression level of genes. Briefly, first-strand cDNA was reversely transcribed from $2 \mu \mathrm{g}$ of total RNA using an oligo- $(\mathrm{dT})_{15}$ primer and MMLV reverse transcriptase (Clontech) in a 20- $\mu 1$ reaction mixture. The primer pairs and PCR conditions for each gene are listed in Table I. The number of PCR cycles used allowed the quantification without reaching the amplifying plateau for PCR products. As internal standard, a fragment of human endogenous $B$-actin was amplified simultaneously in each PCR reaction. PCR products were resolved on a $2.0 \%$ agarose gel, and the bands were visualized by ethidium bromide staining. The cDNA bands were semiquantified by densitometry measurement. The ratio of the

Table I. Primer pairs and PCR conditions for each gene amplification.

\begin{tabular}{|c|c|c|c|}
\hline Gene & Primer pairs & PCR conditions & Product (bp) \\
\hline BMPR2 & $\begin{array}{l}\text { F: 5' TTTCTGCCCCATCTCCCATACT 3' } \\
\text { R: 5' CTCCCCAAAACCAGAAGCAATA 3' }\end{array}$ & $\begin{array}{l}94^{\circ} \mathrm{C} \text { for } 30 \mathrm{sec}, 54^{\circ} \mathrm{C} \text { for } 30 \mathrm{sec}, \\
72^{\circ} \mathrm{C} \text { for } 20 \mathrm{sec} ; 30 \mathrm{cycles}\end{array}$ & 247 \\
\hline $\mathrm{Cx} 43$ & $\begin{array}{l}\text { F: 5' GCTGAGCCCTGCCAAAGACTGT 3' } \\
\text { R: 5' TCGGGGAAATCAAAAGGCTGTG 3' }\end{array}$ & $\begin{array}{l}94^{\circ} \mathrm{C} \text { for } 30 \mathrm{sec}, 57.5^{\circ} \mathrm{C} \text { for } 30 \mathrm{sec}, \\
72^{\circ} \mathrm{C} \text { for } 20 \mathrm{sec} ; 30 \text { cycles }\end{array}$ & 255 \\
\hline NOL6 & $\begin{array}{l}\text { F: 5' TGCCCCCAGCCCAGGTTAC 3' } \\
\text { R: 5' GGCACGGGCGGAAGAAGTC 3' }\end{array}$ & $\begin{array}{l}94^{\circ} \mathrm{C} \text { for } 30 \mathrm{sec}, 59.1^{\circ} \mathrm{C} \text { for } 30 \mathrm{sec}, \\
72^{\circ} \mathrm{C} \text { for } 20 \mathrm{sec} ; 28 \text { cycles }\end{array}$ & 333 \\
\hline LYK5 & $\begin{array}{l}\text { F: 5' AGGCGGTGGGTCTCGGAAAAGT 3' } \\
\text { R: 5' AGCTCGCCCTGCAAGAATGTTA 3' }\end{array}$ & $\begin{array}{l}94^{\circ} \mathrm{C} \text { for } 30 \mathrm{sec}, 59^{\circ} \mathrm{C} \text { for } 30 \mathrm{sec}, \\
72^{\circ} \mathrm{C} \text { for } 20 \mathrm{sec} ; 30 \mathrm{cycles}\end{array}$ & 294 \\
\hline DKEZP686P0196 & $\begin{array}{l}\text { F: 5' GGCATCCAGGCGTTTCCATACA 3' } \\
\text { R: 5' CACTGCAGCCCCTCTCATCACA 3' }\end{array}$ & $\begin{array}{l}94^{\circ} \mathrm{C} \text { for } 30 \mathrm{sec}, 57^{\circ} \mathrm{C} \text { for } 30 \mathrm{sec}, \\
72^{\circ} \mathrm{C} \text { for } 20 \mathrm{sec} ; 32 \mathrm{cycles}\end{array}$ & 295 \\
\hline MAPK8IP2 & $\begin{array}{l}\text { F: 5' CTCCAGCACCGAGTCCTTTGG 3' } \\
\text { R: 5' GCATGTTGAAGCCACGGAACCA 3' }\end{array}$ & $\begin{array}{l}94^{\circ} \mathrm{C} \text { for } 30 \mathrm{sec}, 60^{\circ} \mathrm{C} \text { for } 30 \mathrm{sec}, \\
72^{\circ} \mathrm{C} \text { for } 20 \mathrm{sec} ; 32 \mathrm{cycles}\end{array}$ & 182 \\
\hline XPC & $\begin{array}{l}\text { F: 5' AGG CAA AAC ACA TGG ACC AG 3' } \\
\text { R: 5' AGT AGA CCG CTT CTC CAC GAC 3' }\end{array}$ & $\begin{array}{l}94^{\circ} \mathrm{C} \text { for } 30 \mathrm{sec}, 56.5^{\circ} \mathrm{C} \text { for } 30 \mathrm{sec}, \\
72^{\circ} \mathrm{C} \text { for } 20 \mathrm{sec} ; 25 \text { cycles }\end{array}$ & 335 \\
\hline B-actin & $\begin{array}{l}\text { F: 5' GCCAGGTCCAGACGCAGGAT 3' } \\
\text { R: 5' CGGTCCAGGTGTGTCCTA 3' }\end{array}$ & $\begin{array}{l}94^{\circ} \mathrm{C} \text { for } 30 \mathrm{sec}, 56.2^{\circ} \mathrm{C} \text { for } 30 \mathrm{sec} \\
72^{\circ} \mathrm{C} \text { for } 20 \mathrm{sec} ; 22 \mathrm{cycles}\end{array}$ & 127 \\
\hline
\end{tabular}

F, forward; R, reverse 
specific gene intensity signal to the $\beta$-actin intensity signal was used for semi-quantitative analysis expressed by the relative mRNA level.

To quantify the mRNA level of the XPC gene, quantitative real-time PCR was performed on CFD-3240 Chromo4 ${ }^{\mathrm{TM}}$ continuous fluorescence detector system (MJ Research, Inc., Watertown, MA, USA), using $10 \mu 1$ of DyNAmo ${ }^{\text {TM }}$ SYBR $^{{ }_{-}}$ Green qPCR master mix containing the modified Thermus brockianus hot start DNA polymerase (Finnzymes Oy, Espoo, Finland), $0.2 \mu \mathrm{M}$ of each primer and $2 \mu \mathrm{l}$ cDNA template (obtained after RT as described above) in a $20-\mu 1$ final volume. The amplification was started by a $10-\mathrm{min}$ incubation at $95^{\circ} \mathrm{C}$ to denature the template cDNA and activate Taq polymerase, then followed by 34 cycles consisting of denaturation at $95^{\circ} \mathrm{C}$ for $20 \mathrm{sec}$, annealing at $58.8^{\circ} \mathrm{C}$ for $20 \mathrm{sec}$, and synthesis at $72^{\circ} \mathrm{C}$ for $20 \mathrm{sec}$. To measure the PCR products generated in the presence of SYBR-Green $I, a T_{m}$ analysis was performed by increasing the temperature from $65-90^{\circ} \mathrm{C}$ at a linear transition rate of $0.2^{\circ} \mathrm{C} / \mathrm{sec}$. Fluorescence was monitored continuously while the temperature was increased and data were collected using Option Monitor2 software (MJ Research, Inc.). The standard curve was plotted using Origin 5.0 software (Microcal Software, Inc., Northampton, MA, USA). The cycle number at which the fluorescent signal crossed the detection threshold was denoted as the threshold cycle (CT). CT values obtained for the $X P C$ gene were normalized using the $\beta$-actin gene as the internal standard. Each PCR reaction was run in triplicate in three independent experiments.
Table II. The numbers of genes with changed transcription levels in the irradiated AHH-1 cells.

\begin{tabular}{lccccc}
\hline $\begin{array}{l}\text { Expression } \\
\text { changes }\end{array}$ & $0.05 \mathrm{~Gy}$ & $0.2 \mathrm{~Gy}$ & $0.5 \mathrm{~Gy}$ & $2.0 \mathrm{~Gy}$ & $10.0 \mathrm{~Gy}$ \\
\hline Up-regulated & 25 & 21 & 30 & 32 & 26 \\
Down-regulated & 18 & 62 & 45 & 46 & 219 \\
\hline
\end{tabular}

Northern blot analysis. Total RNA $(15 \mu \mathrm{g})$ was fractionated on a $1.2 \%$ formaldehyde agarose gel, transferred onto a Duralon-UV membrane (Stratagene), and hybridized to [ $\left.\alpha{ }^{-32} \mathrm{P}\right] \mathrm{dCTP}$-labeled $C x 43, P 53 I P 3$ or XPC cDNA probe. The glyceraldehyde 3 '-phosphate dehydrogenase (GAPDH) cDNA probe was used as the internal control for the quantity of the loaded RNA sample.

Western blot analysis. The cells were harvested and washed twice in ice-cold phosphate-buffered saline. Cell pellets $\left(0.5-1 \times 10^{6}\right)$ were incubated in $100 \mu 1$ of Master lysis buffer $\left(\mathrm{M}-\mathrm{PER}^{\mathrm{TM}}\right.$ mammalian protein extraction reagent) (Pierce, Rockford, IL, USA) for 5-8 min at room temperature. After centrifugation for $15 \mathrm{~min}$ at $4^{\circ} \mathrm{C}$, whole protein extract was harvested and the protein concentration was determined. A total of $20 \mu \mathrm{g}$ of proteins was resolved on $8 \%$ SDS/PAGE and transferred onto a polyvinylidene fluoride (PVDF) membrane. The immunohybridization was performed using the anti-Connexin 43 polyclonal antibody (\#66-0700, Zymed), or

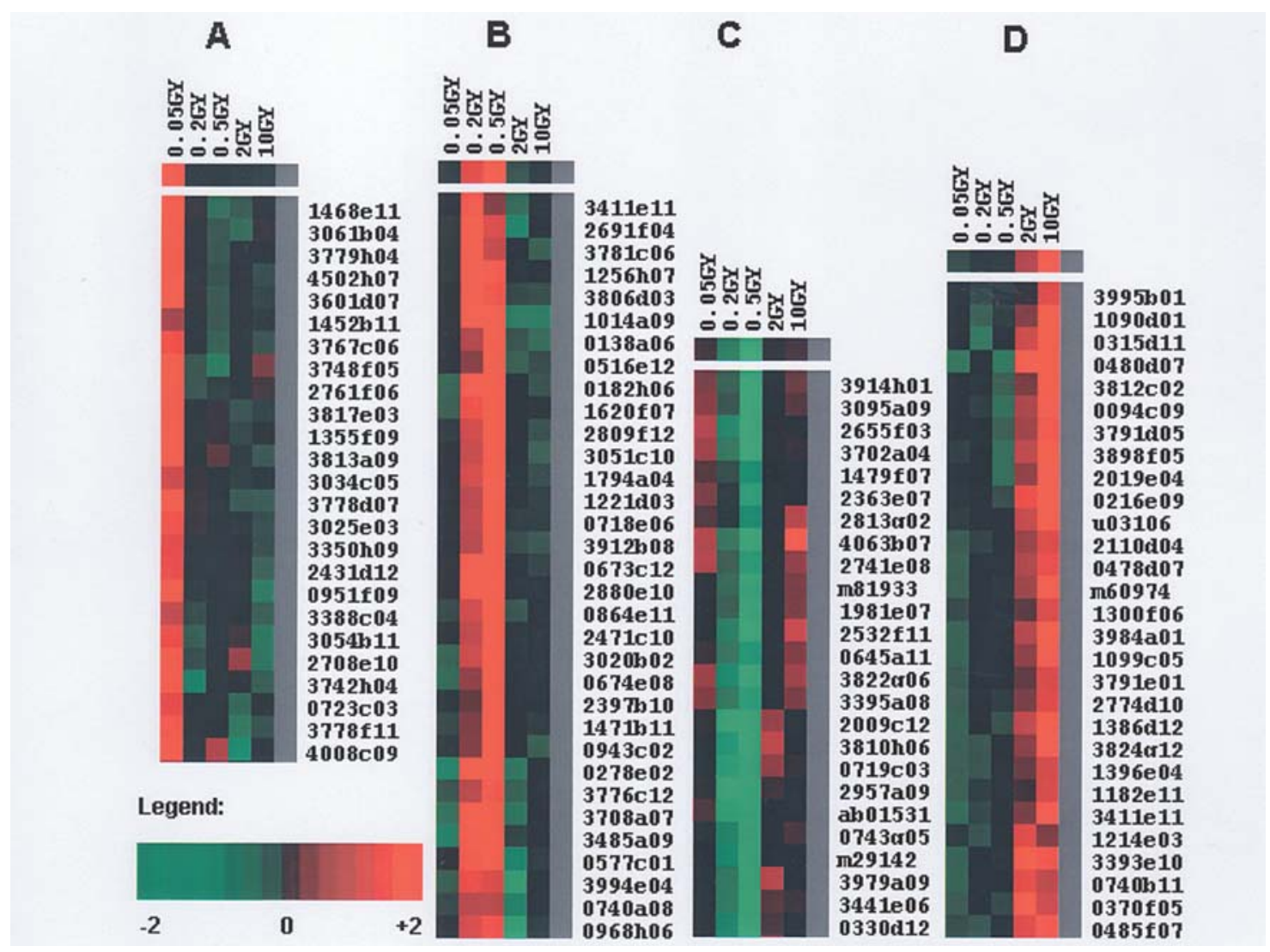

Figure 1. The cluster analysis representative of transcriptional profiles of AHH-1 cells $4 \mathrm{~h}$ after exposure to 0.05-, 0.2-, 0.5-, 2- and 10-Gy $\gamma$-rays. The cluster analysis (K-mean) was performed using Genomic Profiler software. This figure shows the genes whose expression was increased (red color; A, B, D) or decreased (green color, $\mathrm{C}$ ) by radiation as compared with those of the sham-irradiated cells. Overlapping of the increased expression genes was also observed between 0.2 and $0.5 \mathrm{~Gy}(\mathrm{~B})$ or 2 and $10 \mathrm{~Gy}(\mathrm{D})$, as well as that of the decreased expression genes between 0.2 and $0.5 \mathrm{~Gy}(\mathrm{C})$. 
Table III. The list of up-regulated genes by 0.05 -Gy low-dose irradiation.

\begin{tabular}{|c|c|c|c|c|}
\hline \multirow[t]{2}{*}{ Genbank no. } & \multirow[t]{2}{*}{ Gene definition } & \multicolumn{3}{|c|}{ Changed fold } \\
\hline & & Exp 1 & $\operatorname{Exp} 2$ & Average \\
\hline NM_000828 & Glutamate receptor, ionotrophic, AMPA 3 (GRIA3) & 1.960 & 2.048 & 2.004 \\
\hline NM_022917 & Nucleolar protein family 6 (RNA-associated) (NOL6) & 2.042 & 2.034 & 2.038 \\
\hline NM_020193 & Chromosome 11 open reading frame 30 , ENT domain containing & 2.061 & 2.101 & 2.081 \\
\hline NM_001204 & $\begin{array}{l}\text { Bone morphogenetic protein receptor, type II } \\
\text { (serine/threonine kinase) (BMPR2) }\end{array}$ & 2.226 & 2.084 & 2.155 \\
\hline NM_000165 & Gap junction protein, $\alpha 1,43-\mathrm{kDa}$ (connexin 43) (GJA1) & 2.146 & 2.160 & 2.150 \\
\hline NM_001003954 & Annexin A13 (ANXA13) & 2.070 & 2.252 & 2.161 \\
\hline BX436525 & Unknown & 2.382 & 2.561 & 2.422 \\
\hline BX537946 & EPH_lbd, FN3, TyrKc and SAM domain-containing & 1.924 & 3.588 & 2.506 \\
\hline NM_016524 & Homo sapiens B/K protein (LOC51760) & 2.201 & 2.806 & 2.506 \\
\hline BC043641 & Homo sapiens protein kinase LYK5 & 2.519 & 2.515 & 2.517 \\
\hline NM_032777 & G protein-coupled receptor 124 (GPR124) & 2.524 & 2.516 & 2.520 \\
\hline NM_012324 & $\begin{array}{l}\text { Mitogen-activated protein kinase } 8 \text { interacting protein } 2 \\
\text { (MAPK8IP2), or the JNK-interacting protein } 2 \text { (JIP2) }\end{array}$ & 2.508 & 2.546 & 2.527 \\
\hline $\mathrm{BC} 028683$ & Human PRP39 pre-mRNA processing factor 39 homolog (yeast) & 2.340 & 4.064 & 3.202 \\
\hline BX538266 & Unknown, cDNA DKFZp686P0190 & 3.240 & 3.212 & 3.226 \\
\hline NM_018046 & Angiogenic factor with G patch and FHA domains 1 (AGGF1) & 3.846 & 2.812 & 3.330 \\
\hline
\end{tabular}

anti-ß-actin polyclonal antibody (\#I-19, Santa Cruz) and then the IgG-HRP secondary antibody (Zhongshan Company, Beijing, P.R.China). Bands were visualized using chemiluminescence (Santa Cruz) according to the manufacturer's instructions.

\section{Results}

Comparison of transcriptional profiles of AHH-1 cells after exposure to different doses of $\gamma$-rays. Two independent BiostarH-140s microarray hybridizations were carried out for each radiation dose with $\mathrm{Cy} 3$ - or Cy5-labeled cDNAs obtained after RT of RNA extracted from human lymphoblastoid AHH-1 cells harvested $4 \mathrm{~h}$ after $0.05,0.2,0.5,2.0$ and 10.0 Gy of $\gamma$-ray exposure or sham-irradiation. The genes modulated at least 2-fold in average but at least 1.9-fold in each individual microarray experiment were considered as reliable radiation-responsive genes. By choosing these criteria of analysis, the number of radiation-inducible genes ranged from 43-245 genes, i.e. $\sim 0.5-2 \%$ of the total genes on the microarray, according to the dose tested (Table II). Upand down-regulated genes were almost equally distributed in the 0.05-, 0.5- and 2-Gy sets. In contrast, the transcriptional alterations after $10 \mathrm{~Gy}$, which is a supra-lethal dose, included mostly down-regulations $(219 / 245,90 \%)$. Fig. 1 shows the clustering analysis representative of the genes with altered expression. It is clear that a certain set of genes was induced by a specific dose or dose range.
Even a dose as low as 0.05 Gy was effective in eliciting a transcriptional response (Table III). Some of these genes with a 2-fold increased expression induced by $0.05 \mathrm{~Gy}$ are involved in signaling pathways (BMPR2, GPR124, JIP2/MAPK8IP2 and AGGF1), intercellular transport/ cell-cell communication (ANXA13, Connexin 43) or ion channeling/neurotransmitting (GRIA3/GLUR3).

A set of 0.2-Gy-inducible genes was also identified. The 0.2-Gy up-regulated genes include those belonging to i) signal transduction: RAS protein activator-like 2 (RASAL2), human lymph node homing receptor mRNA, killer cell lectin-like receptor subfamily $\mathrm{C}$ member 2 (KLRC2), vitronectin (serum spreading factor somatomedin B complement S-protein) (VTN) and plexin A4 (PLXNA4); ii) transcription or DNA-binding factors: retinoblastomaassociated factor 600 , ring finger protein 2 (RNF2); iii) cytoskeleton and cell movement: prickle-like 2 (Drosophila) (PRICKLE2), Homo sapiens a disintegrin-like and metalloprotease (reprolysin type) with thrombospondin type 1 motif 1 (ADAMTS1), radial spokehead-like 3 (RSHL3); and iv) cell adhesion: latent transforming growth factor $B$ binding protein 2 (LTBP2), protocadherin $\alpha 9$ (PCDHA9) and protocadherin 18 (PCDH18).

We observed few genes showing a significant alteration of expression simultaneously at both $0.2-$ and $0.5-$ Gy doses at the 2-fold threshold. However, if the threshold was reduced to 1.8 -fold, some genes were affected by both $0.2 \mathrm{~Gy}$ and 0.5 Gy. These included the up-regulated genes such as 


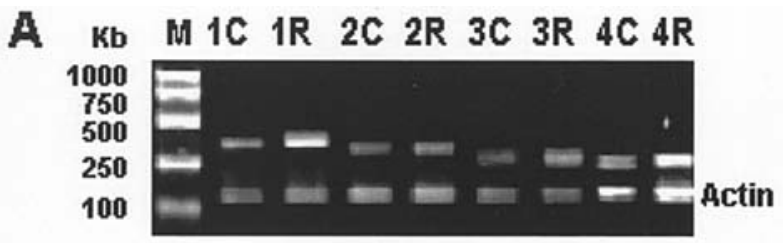

B
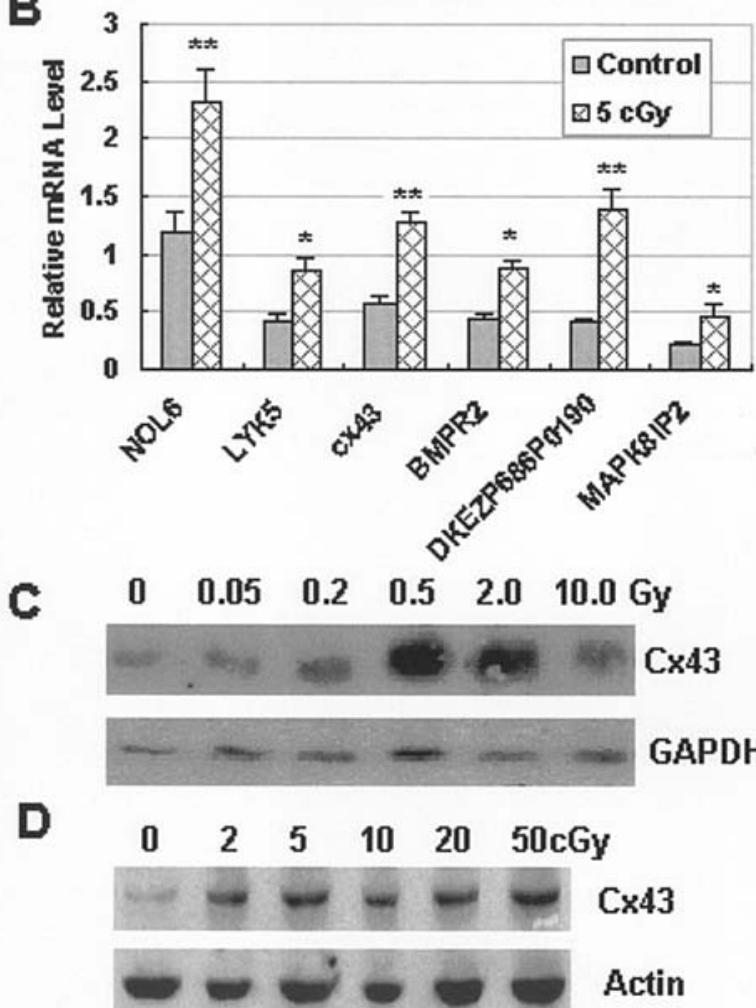

Figure 2. Confirmation of gene expression changes selected from the microarray analysis by semi-quantitative RT-PCR. (A) Representative electrophoresis gel image of RT-PCR products amplified from the shamcontrol (C) and 0.05-Gy-irradiated (R) samples prepared at $4 \mathrm{~h}$ after irradiation. M, DNA marker; 1, NOL 6; 2, LYK5; 3, connexin 43 (Cx 43), 4, BMPR2. (B) Semi-quantification of PCR products. The human B-actin gene was used as the internal standard. The relative mRNA level was calculated by the ratio of the selected gene amplification product to the $\beta$-actin gene amplification product. Each bar represents the means \pm SD from 3 independent experiments. Student's t-test: ${ }^{*} \mathrm{P}<0.05,{ }^{* *} \mathrm{P}<0.01$ as compared with the sham-irradiated samples. (C) Northern blot analysis of Cx 43 mRNA expression $4 \mathrm{~h}$ after exposure to different doses of $\gamma$-rays. (D) Western blot analysis of Cx 43 protein expression $4 \mathrm{~h}$ after exposure to different doses of $\gamma$-rays.

tumor protein p53 inducible protein 3 (TP53I3), xeroderma pigmentosum complementation group $\mathrm{C}(X P C)$, the human chromodomain helicase DNA binding protein 6 gene (CHD6), mitogen-activated protein kinase kinase kinase 7 interacting protein 2 gene (MAP3K7IP2), G protein-coupled receptor 56 gene (GPR56), Homo sapiens protocadherin $\alpha 9$ (PCDHA9) and several unknown genes; and the downregulated genes such as vav 1 oncogene (VAV1), phosphomevalonate kinase $(P M V K)$, lymphocyte cytosolic protein 1 (L-plastin) ( $L C P 1)$, fibrinogen-like 2, human egl nine homolog 2 ( $E G L N 2)$, protein tyrosine phos-phatase type IVA, member 2 (PTP4A2) and serine (or cysteine) proteinase inhibitor, clade D (heparin cofactor) member 1, and some unknown genes.
There were 245 genes showing an altered expression induced by $10 \mathrm{~Gy}$, the largest number of radiation-inducible genes among all the investigated doses. Most of these 10-Gyresponsive genes $(90 \%)$ were depressed. The detailed lists of the altered expression genes at $2 \mathrm{~Gy}$ and $10 \mathrm{~Gy}$ are available upon request.

Most importantly, we identified a number of genes that exhibited a dose-dependent trend of increased (Table IV), or depressed (Table V) expression induced by IR, i.e. the extent of up- and down-regulation augmented along with the increase of radiation dose.

Validation of altered expression of radiation-inducible genes selected in microarray assay. The altered expression of 0.05-Gy low-dose-responsive genes BMPR2, Connexin 43, LYK5, NOL6, MAPK8IP2 and cDNA clone DKEZP686P0190 were validated by semi-quantitative RT-PCR (Fig. 2A and B). Our microarray analysis demonstrated that the Connexin 43 gene was up-regulated by the $0.05-\mathrm{Gy}$ low dose of $\gamma$ rays as previously reported after exposure to low-dose $\alpha$ particles (25). We further confirmed this induction of Connexin 43 at the transcriptional level by Northern blot hybridization (Fig. 2C) as well as at the translational level by Western blot analysis (Fig. 2D).

Xeroderma pigmentosum complementation group $\mathrm{C}$ gene $(X P C)$ and tumor protein p53 inducible protein 3 gene (TP53I3) were shown up-regulated in a dose-dependent trend within the dose range $0.05-10 \mathrm{~Gy}$ in our microarray assays. The Northern blot analyses confirmed a clear dose-dependent inducible expression of both XPC (Fig. 3A) and TP53I3 (Fig. 3B). Using quantitative real-time PCR, we further quantified the expression of the $X P C$ gene after radiation. As shown in Fig. 3C, the expression level of $X P C$ was increased in a clear dose-dependent manner $4 \mathrm{~h}$ after exposure with different doses from 0.05-10 Gy. XPC gene induction was also shown to be time-dependent (Fig. 3D), reaching a peak $4 \mathrm{~h}$ after $2 \mathrm{~Gy}$, and then declining at $10 \mathrm{~h}$. The $0.05-\mathrm{Gy}$ low dose was also effective in inducing $X P C$ expression, with a maximum increase at $10 \mathrm{~h}$ after IR (1.93-fold), which occurred at later times and was lower than after 2-Gy irradiation (3.2-fold) (Fig. 3D).

\section{Discussion}

The severities of IR-induced biological effects in mammalian cells are highly associated with the radiation quality (LET, nature of the induced lesion) as well as radiation doses or dose rates. Even other factors such as cell cycle phase, radical scavenger level, DNA repair status influence the fate of irradiated cells. Tissue injury or a cellular reaction may be induced by doses over a threshold, with the most severe cytotoxic effects or tissue reaction caused by acute exposure to high doses. With regard to low-dose exposure, a more complex scenario of cellular responses has been portrayed as suggested by the existence of the adaptive response (1-7), bystander effects $(3,4,11,30-32)$ and hyper-radiosensitivity phenomenon $(8,9,33,34)$. It is believed that these diverse cellular responses to IR are at least partially dependent on the specific induction of some genes. Here we used microarray to simultaneously investigate the global transcriptional 
A

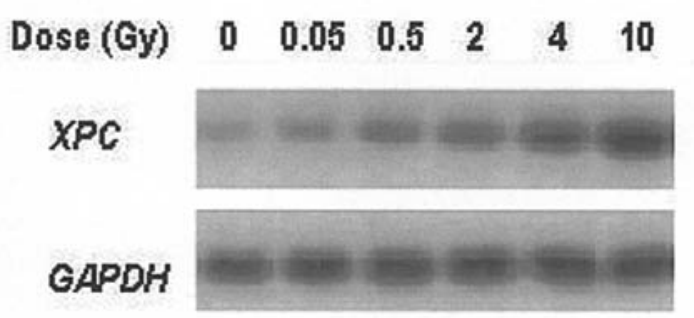

C

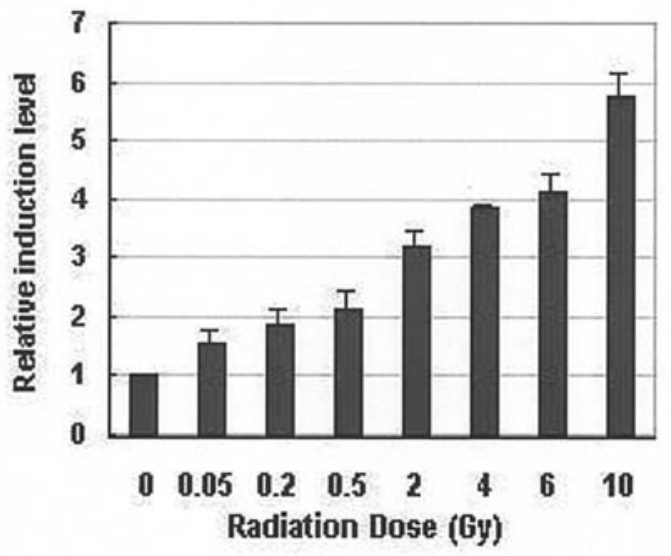

B

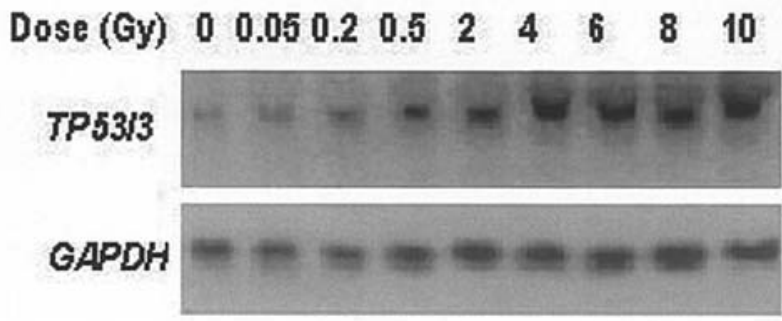

D

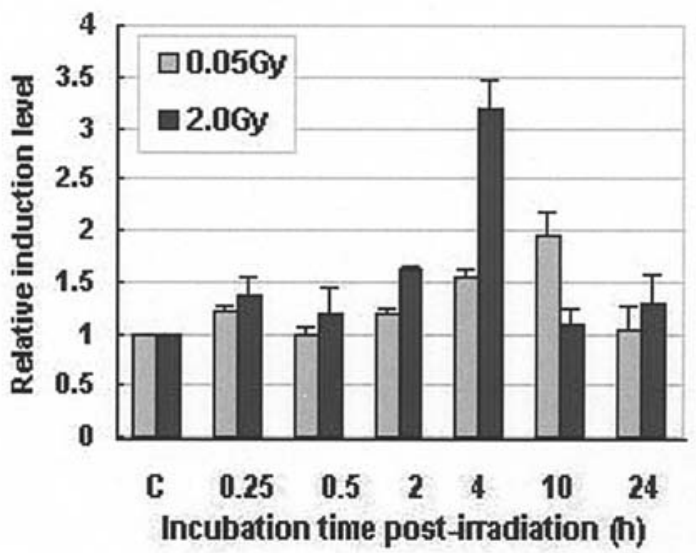

Figure 3. Validation of radiation-induced expression changes of the TP53I3 and XPC genes in AHH-1 cells. (A) Dose-responsive change of TP53I3 gene expression detected by Northern blot hybridization. (B) Dose-responsive change of XPC gene expression detected by Northern blot hybridization. (C) Doseresponsive change of XPC gene expression detected by quantitative RT-PCR. (D) Time-dependent change of XPC gene expression in AHH-1 cells detected by quantitative RT-PCR. Each bar of data represents the means \pm SD from 3 independent experiments.

Table IV. The list of up-regulated genes with a dose-dependent tendency. ${ }^{\mathrm{a}}$

\begin{tabular}{|c|c|c|c|c|c|c|}
\hline Accession no. & Definition & $0.05 \mathrm{~Gy}$ & $0.2 \mathrm{~Gy}$ & 0.5 Gy & $2.0 \mathrm{~Gy}$ & 10 Gy \\
\hline AK091115 & $\begin{array}{l}\text { Highly similar to mRNA for seven transmembrane } \\
\text { protein TM7SF3 }\end{array}$ & 0.875 & 1.458 & 2.044 & 2.339 & 1.946 \\
\hline NM_002527 & Neurotrophin 3 (NTF3) & 0.989 & 1.452 & 1.801 & 1.965 & 2.395 \\
\hline BE889962 & Unknown & 1.149 & 1.683 & 2.149 & 2.412 & 2.677 \\
\hline NM_004879 & Etoposide-induced 2.4 mRNA (EI24) & 1.022 & 1.543 & 1.652 & 2.624 & 2.727 \\
\hline NM_023039 & Ankyrin repeat, family A (RFXANK- like), 2 (ANKRA2) & 1.071 & 1.377 & 1.623 & 2.556 & 2.835 \\
\hline NM_147188 & F-box protein $22(\mathrm{FBXO} 22)$ & 1.248 & 1.454 & 1.686 & 2.613 & 2.846 \\
\hline NM_016545 & Immediate early response 5 (IER5) & 1.071 & 1.354 & 1.608 & 2.018 & 2.876 \\
\hline NM_001001342 & $\begin{array}{l}\text { Biogenesis of lysosome-related organelles complex-1, } \\
\text { subunit } 2 \text { (BLOC1S2) }\end{array}$ & 1.241 & 1.560 & 1.609 & 2.176 & 3.321 \\
\hline D87328 & mRNA for HCS & 1.343 & 1.571 & 1.633 & 2.223 & 3.464 \\
\hline BE896331 & Unknown & 1.075 & 1.241 & 1.542 & 2.309 & 3.563 \\
\hline AK055972 & cDNA FLJ31410 fis, highly similar to MDS025 mRNA & 0.896 & 1.243 & 1.442 & 2.173 & 3.622 \\
\hline NM_004628 & Xeroderma pigmentosum complementation group C (XPC) & 1.218 & 1.830 & 1.923 & 2.903 & 3.752 \\
\hline BU729993 & UI-E-CK1-afi-b-20-0-UI & 0.919 & 1.781 & 2.382 & 2.727 & 3.882 \\
\hline AK123575 & Unknown & 1.037 & 1.476 & 2.494 & 2.341 & 4.056 \\
\hline NM_004881 & Tumor protein p53 inducible protein 3 (TP53I3) & 0.992 & 1.878 & 1.984 & 6.872 & 5.461 \\
\hline
\end{tabular}

aThe data are the average from two independent microarray experiments. 
Table V. The list of down-regulated genes with dose-dependent tendency. ${ }^{\mathrm{a}}$

\begin{tabular}{|c|c|c|c|c|c|c|}
\hline Genbank no. & Definition & 0.05 Gy & 0.2 Gy & 0.5 Gy & 2.0 Gy & $10 \mathrm{~Gy}$ \\
\hline NM_012218 & Interleukin enhancer binding factor 3 (ILF3) & 0.838 & 0.590 & 0.315 & 0.330 & 0.151 \\
\hline AB058767 & Unknown & 0.740 & 0.632 & 0.293 & 0.330 & 0.156 \\
\hline XM_035299 & Zinc finger, SWIM domain-containing 6 & 0.783 & 0.571 & 0.405 & 0.534 & 0.173 \\
\hline NM_002444 & Moesin (MSN), mRNA & 0.680 & 0.537 & 0.319 & 0.386 & 0.189 \\
\hline AK090828 & Unknown & 0.879 & 0.840 & 0.353 & 0.621 & 0.197 \\
\hline NM_002298 & Lymphocyte cytosolic protein 1 (LCP1) & 0.930 & 0.512 & 0.297 & 0.372 & 0.202 \\
\hline AK092904 & Unknown & 0.846 & 0.626 & 0.511 & 0.443 & 0.221 \\
\hline AK127479 & Unknown & 0.744 & 0.703 & 0.332 & 0.345 & 0.226 \\
\hline NM_018639 & WD repeat and SOCS box-containing 2 (WSB2) & 0.929 & 0.620 & 0.676 & 0.483 & 0.240 \\
\hline BX647112 & Unknown & 0.898 & 0.618 & 0.535 & 0.488 & 0.251 \\
\hline NM_018031 & WD repeat domain 6 (WDR6) & 0.768 & 0.780 & 0.530 & 0.622 & 0.261 \\
\hline NM_025182 & Unknown & 0.919 & 0.662 & 0.594 & 0.571 & 0.262 \\
\hline AK092677 & Unknown & 1.047 & 0.706 & 0.569 & 0.377 & 0.283 \\
\hline NM_016343 & Centromere protein $\mathrm{F}$ (mitosin) (CENPF) & 0.784 & 0.859 & 0.739 & 0.522 & 0.290 \\
\hline AK022952 & Unknown & 1.173 & 0.860 & 0.722 & 0.616 & 0.308 \\
\hline NM_005347 & Heat shock 70-kDa protein 5 (HSPA5) & 1.149 & 0.753 & 0.639 & 0.547 & 0.321 \\
\hline NM_001976 & Enolase 3 ( $\beta$, muscle) (ENO3) & 0.983 & 0.588 & 0.626 & 0.438 & 0.336 \\
\hline ВC065016 & Human AFG3 ATPase family gene 3-like 2 & 1.119 & 0.864 & 0.686 & 0.557 & 0.338 \\
\hline AK025276 & Unknown & 1.157 & 0.625 & 0.550 & 0.519 & 0.339 \\
\hline AK000498 & Unknown & 0.831 & 0.630 & 0.761 & 0.551 & 0.355 \\
\hline NM_152840 & Hermansky-Pudlak syndrome 4 (HPS4) & 1.205 & 0.777 & 0.516 & 0.338 & 0.366 \\
\hline AK091498 & Unknown & 1.318 & 0.647 & 0.684 & 0.577 & 0.372 \\
\hline BX538251 & Unknown & 0.915 & 0.899 & 0.403 & 0.631 & 0.373 \\
\hline ВC020516 & Interferon regulatory factor 2 binding protein 2 & 0.941 & 0.821 & 0.884 & 0.554 & 0.388 \\
\hline NM_015981 & $\begin{array}{l}\text { Calcium/calmodulin-dependent protein kinase II } \alpha \\
\text { (CAMK2A) }\end{array}$ & 0.761 & 0.656 & 0.581 & 0.596 & 0.390 \\
\hline ВC012731 & Human Mak3 homolog (S. cerevisiae) & 0.885 & 0.616 & 0.460 & 0.524 & 0.391 \\
\hline BG115862 & Unknown & 0.846 & 0.776 & 0.803 & 0.645 & 0.394 \\
\hline AK128054 & Unknown & 0.941 & 0.827 & 0.538 & 0.683 & 0.413 \\
\hline BM664759 & Unknown & 0.877 & 0.766 & 0.770 & 0.691 & 0.422 \\
\hline NM_015059 & Homo sapiens talin 2 (TLN2), mRNA & 0.882 & 0.722 & 0.717 & 0.539 & 0.450 \\
\hline
\end{tabular}

${ }^{a}$ The data are the average from two independent microarray experiments.

changes occurring during the early response to irradiation $(4 \mathrm{~h})$ in human lymphoblastoid AHH-1 cells exposed to different doses from 0.05-10 Gy. Our data demonstrated that the alterations in gene expression induced by IR were actually related with the radiation dose.

It has been widely reported that an adaptive response can be induced by a few cGy in various cell lines including AHH-1 cells, while its relevant molecular mechanism is still unclear. Our microarray data showed that 0.05 Gy was effective in inducing the expression of a set of genes (Table III), including those involved in signal transduction pathways regulating the proliferation in various cell types, among which MAPK8IP2 was originally described as a member of the putative scaffold protein family implicated in the regulation of JNK signaling modules and named JIP2 [the cJun $\mathrm{NH}_{2}$-terminal kinase (JNK)-interacting protein 2] (35).
MAPK8IP2 is a scaffold for the p38 mitogen-activated protein (MAP) kinase cascade in mammalian cells because of its binding to the Rac target Mixed lineage kinase 3 (MLK3), the MAP kinase kinase MKK3, and the p38 MAP kinase $(36,37)$. Furthermore, it can bind to and be modified by the Rac GEFs Tiam 1 and Ras-GRF1, which are guanine nucleotide exchange factors (GEFs) that activate the Rac GTPase, suggesting a mechanism connecting a scaffold for the p38 kinase cascade to upstream regulatory proteins $(36,37)$. It is well known that p38 MAP kinases, including

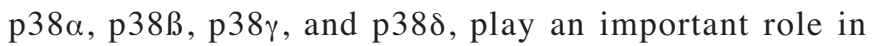
mediating cellular responses to both environmental stresses and proinflammatory cytokines. The p38 MAPK signaling pathway was suggested to play a role in the adaptive response of low-dose radiation via a rapid and robust circuitous feedback signal transduction pathway involving 
activation of protein kinase $\mathrm{C}(\mathrm{PKC}) \alpha$ and p38MAPK in mouse m5S cells (38). The MAPK pathway was also shown recently to be involved in bystander response (39). Our observation of the inducible expression of MAPK8IP2/JIP2 by $0.05 \mathrm{~Gy}$ in human AHH-1 cells further implies the involvement of the p38 MAPK signaling pathway in mediating cellular responses to low-dose radiation.

Connexin 43, one of the 0.05-Gy-inducible genes, has been described to be up-regulated by $\alpha$-particles at a dose as low as $0.03 \mathrm{~Gy}$ in normal human skin fibroblasts (25). In the present study, Connexin 43 and another intercellular transport/ communication component ANXA13 were also found to be up-regulated by 0.05 Gy in AHH-1 cells, further suggesting the involvement of intercellular communication in the lowdose response.

We recently reported a set of 0.5-Gy-responsive genes in AHH-1 cells (29). A radiation dose of $\sim 0.5$ Gy was shown to result in a hyper-radiosensitivity response (HRS), another low-dose radiation-induced biological effect defining the phenomenon by which mammalian cells respond to radiation doses $<0.5 \mathrm{~Gy}$ as compared to a high-dose response. Here we further revealed a number of 0.2-Gy-responsive genes, including those involved in signal transduction pathways or receptor networks, cytoskeleton and cell movement, cell adhesion and transcription or DNA-binding factors. If the 2fold threshold of increase or decrease in signal intensity was adjusted to 1.8-fold, a series of genes could be considered to be modulated by both 0.2 - and 0.5 -Gy irradiation, including up-regulated genes (TP53I3, XPC, CHD6, MAP3K7IP2, GPR56, PCDHA9) and down-regulated genes including DNA repair gene $X R C C 4$, vav 1 proto-oncogene (VAVI), phosphomevalonate kinase gene $(P M V K)$, lymphocyte cytosolic protein 1 (L-plastin) gene (LCP1), fibrinogen-like 2 , human egl nine homolog 2, protein tyrosine phosphatase type IVA member 2 gene (PTP4A2) and serine (or cysteine) proteinase inhibitor gene, clade $\mathrm{D}$ (heparin cofactor) member 1 gene. From these, CHD6 was further confirmed to have induced expression by 0.2 or 0.5 Gy in A549 and HeLa cells (29), while the A549 cells were documented to exhibit hyperradiosensitivity (HRS) (34). SiRNA-mediated depression of CHD6 resulted in an increased radioresistance to radiation up to $2 \mathrm{~Gy}$, but barely affected the sensitivity of cells at higher doses (29).

After a 10-Gy high dose, the transcriptional response included the greater number of genes ( 245 genes) which were predominantly depressed. These down-regulated genes can be grouped into functional categories: signal transduction, chromatin dynamic and cell cycle, transcription regulator or DNA-banding factor, cytokeleton and cell movement and immunological regulation. Some of these genes were also altered by 2-Gy irradiation (Table IV and V). The detailed lists are available upon request.

In this study, we highlighted the IR-inducible genes whose expression was depressed or increased in a dosedependent trend from a $0.05-\mathrm{Gy}$ low dose to a 10-Gy high dose (Table IV and Table V). From these inducible genes, the altered expression of XPC and TP53I3 was particularly studied because of its role in global genomic repair (XPC) or the p53 pathway (TP53I3), respectively. Our data are consistent with the observation of a 5-fold increase in the expression of $X P C$ in human lymphoid TK6 cells $4 \mathrm{~h}$ after $10 \mathrm{~Gy}$ (40). IR-induced expression of XPC was also shown to depend on the dose rate (26). While it was recently described that the expression level of XPC was variable $4 \mathrm{~h}$ after irradiation and no distinct pattern was detected, at $24 \mathrm{~h}$ XPC expression was variable at the lower doses of $0.5,1$, and 5 Gy in contrast to the robust decrease in expression at the 10- and 20-Gy doses also in TK6 cells (41). Our microarray assay, Northern blot analysis and quantitative real-time PCR data showed a clear dose-dependent induction of the XPC gene in AHH-1 cells $4 \mathrm{~h}$ after irradiation with doses from 0.05-10 Gy. Our data also indicated that the accumulation of XPC mRNA increased in a time-dependent manner, reaching a peak at $4 \mathrm{~h}$ and gradually returning to a constitutive level at 10-24 h after exposure to 2 Gy. After a 0.05-Gy low-dose irradiation, the accumulation of XPC mRNA reached a peak at $10 \mathrm{~h}$ and declined to a constitutive level at $24 \mathrm{~h}$.

It is well known that the p53 tumor suppressor plays a key role in mediating apoptosis and the cell cycle checkpoint by various intracellular and extracellular signals including IR. A number of proteins have been identified to be involved in the p53 pathway, including PCNA, CDKN1A/p21, MDM2, GDF15, TNFRSF10B/TRAIL-R2, TP53I3/PIG3 and GADD45 (42). Among these p53 target genes, TP53I3 was proposed to participate in the process of $\mathrm{p} 53$-dependent apoptosis through reactive oxygen species (ROS) modulation, and its inducible expression was mediated by p53 mainly via a microsatellite (TGYCC)(n) located in its 5'upstream regulatory region and not through a classical ElDeiry consensus sequence $(43,44)$. Interestingly, an increased expression of TP53I3 was found in AHH-1 cells $4 \mathrm{~h}$ after IR in a clear dose-dependent manner. The biological significance and its mechanism, such as the involvement in apoptosis induction and increased expression of TP53I3 in response to ionizing radiation warrant further investigation.

Taken together, we identified a series of ionizing radiationinducible genes, some of which showed altered transcription levels in a clear dose-dependent manner. These transcriptional responses will not only expand our understanding of the mechanisms of cellular responses to ionizing radiation but will also provide candidates for developing potential biomarkers, which can be used to monitor or predict radiation injury.

\section{Acknowledgements}

The authors wish to thank Dr Odile Rigaud for the critical reading of and editorial assistance with this manuscript. This study was supported by grants from the Chinese National High Technology '863' Programs (grant no. 2004AA221160) and the Chinese National Natural Science Foundation (grant no. 30371232).

\section{References}

1. Kaiser J: Hormesis: a healthful dab of radiation? Science 302: 378, 2003.

2. Mitchel RE, Jackson JS and Carlisle SM: Upper dose thresholds for radiation-induced adaptive response against cancer in highdose-exposed, cancer-prone, radiation-sensitive Trp53 heterozygous mice. Radiat Res 162: 20-30, 2004. 
3. Mothersill C and Seymour C: Radiation-induced bystander effects and adaptive responses - the Yin and Yang of low dose radiobiology? Mutat Res 568: 121-128, 2004.

4. Preston RJ: Radiation biology: concepts for radiation protection. Health Phys 88: 545-556, 2005.

5. Rigaud O, Papdopoulo D and Moustacchi E: Decreased deletion mutation in radioadapted human lymphoblasts. Radiat Res 133: 94-101, 1993.

6. Sasaki MS, Ejima Y, Tachibana A, Yamada T, Ishizaki K, Shimizu T and Nomura T: DNA damage response pathway in radioadaptive response. Mutat Res 504: 101-118, 2002.

7. Zhou PK and Rigaud O: Down-regulation of the human CDC16 gene after exposure to ionizing radiation: A possible role in the radioadaptive response. Radiat Res 155: 43-49, 2001.

8. Joiner MC, Marples B, Lambin P, Short SC and Turesson I: Low-dose hypersensitivity: current status and possible mechanisms. Int J Radiat Oncol Biol Phys 49: 379-389, 2001.

9. Marples B, Wouters BG and Joiner MC: An association between the radiation-induced arrest of G2-phase cells and lowdose hyper-radiosensitivity: a plausible underlying mechanism? Radiat Res 160: 38-45, 2003.

10. Crompton NE, Barth B and Kiefer J: Inverse dose-rate effect for the induction of 6-thioguanine-resistant mutants in Chinese hamster V79-S cells by 60Co gamma rays. Radiat Res 124 : 300-308, 1990.

11. Chaudhry MA, Chodosh LA, McKenna WG and Muschel RJ: Gene expression profile of human cells irradiated in G1 and G2 phases of cell cycle. Cancer Lett 195: 221-233, 2003.

12. Cucinotta FA, Dicello JF, Nikjoo H and Cherubini R: Computational model of the modulation of gene expression following DNA damage. Radiat Prot Dosimetry 99: 85-90, 2002.

13. Mercier G, Berthault N, Mary1 J, Peyre J, Antoniadis A, Comet JP, Cornuejols A, Froidevaux C and Dutreix M: Biological detection of low radiation doses by combining results of two microarray analysis methods. Nucleic Acids Res 32: e12, 2004.

14. Vallat L, Magdelenat H, Merle-Beral H, Masdehors P, de Montalk GP, Davi F, Kruhoffer M, Sabatier L, Orntoft TF and Delic J: The resistance of B-CLL cells to DNA damageinduced apoptosis defined by DNA microarrays. Blood 101: 4598-4606, 2003.

15. Burns TF and El-Deiry WS: Microarray analysis of p53 target gene expression pattern in the spleen and thymus in response to ionising radiation. Cancer Biol Ther 2: 431-443, 2003.

16. Amundson SA, Do KT, Shahab S, Bittner M, Meltzer P, Trent J and Fornace AJ Jr: Identification of potential mRNA biomarkers in peripheral blood lymphocytes for human exposure to ionizing radiation. Radiat Res 154: 342-346, 2000.

17. Amundson SA, Grace MB, McLeland CB, Epperly MW, Yeager A, Zhan Q, Greenberger JS and Fornace AJ Jr: Human in vivo radiation-induced biomarkers: gene expression changes in radiotherapy patients. Cancer Res 64: 6368-6371, 2004.

18. Boerma M, Schutte-Bart CI, Wedekind LE, Beekhuizen H and Wondergem $\mathrm{J}$ : Effects of multiple doses of ionizing radiation on cytokine expression in rat and human cells. Int J Radiat Biol 79: 889-896, 2003.

19. Snyder AR and Morgan WF. Gene expression profiling after irradiation: clues to understanding acute and persistent responses? Cancer Metastasis Rev 23: 259-268, 2004.

20. Roy D, Calaf G and Hei TK: Profiling of differentially expressed genes induced by high linear energy transfer radiation in breast epithelial cells. Mol Carcinog 31: 192-203, 2001.

21. Jen KY and Cheung VG: Transcriptional response of lymphoblastoid cells to ionizing radiation. Genome Res 13: 2092-2100, 2003.

22. Koike M, Shiomi T and Koike A: Identification of skin injuryrelated genes induced by ionizing radiation in human keratinocytes using cDNA microarray. J Radiat Res 46: 173-184, 2005.

23. Ding LH, Shingyoji M, Chen F, Hwang JJ, Burma S, Lee C, Cheng JF and Chen DJ: Gene expression profiles of normal human fibroblasts after exposure to ionizing radiation: a comparative study of low and high doses. Radiat Res 164: 17-26, 2005.

24. Lanza V, Pretazzoli V, Oliveri G, Pascarella G, Panconesi A and Negri A: Transcriptional responses of human umbilical vein endothelial cells to low dose radiation of ionizing radiation. J Radiat Res 46: 265-276, 2005.
25. Azzam EI, de Toledo SM and Little JB: Expression of connexin43 is highly sensitive to ionizing radiation and other environmental stresses. Cancer Res 63: 7128-7135, 2003.

26. Amundson SA, Lee RA, Koch-Paiz CA, Bittner ML, Meltzer P, Trent JM and Fornace AJ Jr: Differential responses of stress genes to low dose-rate $\gamma$ irradiation. Mol Cancer Res 1: 445-452, 2003 .

27. Fornace AJ Jr, Amundson SA, Do KT, Meltzer P, Trent J and Bittner M: Stress-gene induction by low-dose gamma irradiation. Mil Med 167: 13-15, 2002.

28. Franco N, Lamartine J, Frouin V, Le Minter P, Petat C, Leplat J, Libert F, Gidrol X and Martin MT: Low-dose exposure to gamma rays induces specific gene regulations in normal human keratinocytes. Radiat Res 163: 623-635, 2005.

29. Wang HP, Long XH, Sun ZZ, Rigaud O, Xu QZ, Huang YC, Sui JL, Bai B and Zhou PK: Identification of differentially transcribed genes in human lymphoblastoid cells irradiated with $0.5 \mathrm{~Gy}$ of $\gamma$-ray and the involvement of low dose radiation inducible CHD6 gene in cell proliferation and radiosensitivity. Int J Radiat Biol 82: 181-190, 2006.

30. Nagasawa $\mathrm{H}$ and Little JB: Induction of sister chromatid exchanges by extremely low doses of alpha particles. Cancer Res 52: 6394-6396, 1992 .

31. Azzam EI and Little JB: The radiation-induced bystander effect: evidence and significance. Hum Exp Toxicol 23: 61-65, 2004.

32. Nagasawa H, Peng Y, Wilson PF, Lio YC, Chen DJ, Bedford JS and Little JB: Role of homologous recombination in the alphaparticle-induced bystander effect for sister chromatid exchanges and chromosomal aberrations. Radiat Res 164: 141-147, 2005.

33. Marples B, Lambin P, Skov KA and Joiner MC: Low dose hyper-radiosensitivity and increased radio resistance in mammalian cells. Int J Radiat Biol 71: 721-735, 1997.

34. Wouters BG, Sy AM and Skarsgard LD: Low-dose hypersensitivity and increased radioresistance in a panel of human tumor cell lines with different radiosensitivity. Radiat Res 146: 399-413, 1996.

35. Yasuda J, Whitmarsh AJ, Cavanagh J, Sharma M and Davis RJ: The JIP group of mitogen-activated protein kinase scaffold proteins. Mol Cell Biol 19: 7245-7254, 1999.

36. Buchsbaum RJ, Connolly BA and Feig LA: Interaction of Rac exchange factors tiam 1 and Ras-GRF1 with a scaffold for the p38 mitogen-activated protein kinase cascade. Mol Cell Biol 22: 4073-4085, 2002.

37. Robidoux J, Cao W, Quan H, Daniel KW, Moukdar F, Bai X, Floering LM and Collins S: Selective activation of mitogenactivated protein (MAP) kinase kinase 3 and p38 $\alpha$ MAP kinase is essential for cyclic AMP-dependent UCP1 expression in adipocytes. Mol Cell Biol 25: 5466-5479, 2005

38. Shimizu T, Kato T Jr, Tachibana A and Sasaki MS: Coordinated regulation of radioadaptive response by protein kinase $\mathrm{C}$ and p38 mitogen-activated protein kinase. Exp Cell Res 251: 424-432, 1999.

39. Zhou H, Ivanov VN, Gillespie J, Geard CR, Amundson SA, Brenner DJ, Yu Z, Lieberman HB and Hei TK: Mechanism of radiation-induced bystander effect: role of the cyclooxygenase-2 signalling pathway. Proc Natl Acad Sci USA 102: 14641-14646, 2005.

40. Amundson SA, Patterson A, Do KT and Fornace AJ: A nucleotide excision repair master-switch: p53 regulated coordinate induction of global genomic repair genes. Cancer Biol Ther 1: 145-149, 2002.

41. Akerman GS, Rosenzweig BA, Domon OE, Tsai CA, Bishop ME, McGarrity LJ, Macgregor JT, Sistare FD, Chen JJ and Morris SM: Alterations in gene expression profiles and the DNA-damage response in ionizing radiation-exposed TK6 cells. Environ Mol Mutagen 45: 188-205, 2005.

42. Polyak K, Xia Y, Zweier JL, Kinzler KW and Vogelstein B: A model for p53-induced apoptosis. Nature 389: 300-305, 1997.

43. Contente A, Dittmer A, Koch MC, Roth J and Dobbelstein M: A polymorphic microsatellite that mediates induction of PIG3 by $\mathrm{p} 53$. Nat Genet 30: 315-320, 2002.

44. Contente A, Zischler H, Einspanier A and Dobbelstein M: A promoter that acquired p53 responsiveness during primate evolution. Cancer Res 63: 1756-1758, 2003. 